https://doi.org/10.31470/2706-7904-2021-16-234-239

\title{
METALINGUISTIC AWARENESS OF RUSSIAN-HEBREW BILINGUAL PRESCHOOLERS (BASED ON THE DEFINITION TEST)
}

Металингвистическое сознание русско-ивритских двуязычных дошкольников (на основе теста определения)

\section{Irina Ovchinnikova}

Dr. Sc. in Philology, Professor

Sechenov University (Russia)

ovchinnikova.ig@1msmu.ru

https://orcid.org/0000-0003-1726-3360

\section{Miriam Minkov}

Ph.D., Lecturer

Tel Aviv University (Israel)

miriamminkov@yahoo.com

https://www.researchgate.net/profile/Miriam-Minkov

\author{
Mila Schwartz \\ Ph.D., Professor, Head of Research Authority \\ Oranim Academic College of Education (Israel) \\ milasch@post.bgu.ac.il \\ Scopus ID $\underline{8915979800}$
}

\begin{abstract}
Our study of Russian-Hebrew bilingual preschoolers' metalinguistic awareness is based on the results of the definition test with 56 children. The results uncover six strategies to generate a definition of concrete nouns in two languages. The preschoolers preferred to how an object functions while explaining the word meaning in both languages. References to the category by hypernyms, synonyms or co-hyponyms cover 10\% of Russian definitions and 5\% of those in Hebrew. The bilinguals often failed to define a noun in Hebrew. They could not find a relevant hypernym, overcoming the difficulty by generating descriptive definitions with a specific qualification of the object. Manipulating the L2 structure, they showed their metalinguistic awareness.
\end{abstract}

Key words: metalinguistic awareness, bilingualism, the definition task. 


\section{Introduction}

Metalinguistic awareness is the ability to reflect and manipulate the system and structure of the language. It is revealed in metalinguistic operations including generating definitions and comparing structures of different languages. We study comprehension of lexical semantics by Russian-Hebrew bilingual children aged $5-6.8$ years through their definitions of the concrete nouns. While defining the lexical meaning, preschoolers reveal their understanding of noun connections and the structure of their lexicon (Minkov et al., 2020). The bilinguals' L1 and L2 vocabularies differ in size and structure; the rich vocabulary stimulates the development of metalinguistic awareness (Altman et al., 2018). Nevertheles, bilingual children show the advanced level of metalinguistic awareness as compared to their monolingual peers; however, they do not outperform them in verbal fluency (Bialystok et al., 2014). Metalinguistic awareness effects the development of the capacity to generate a clear adult-like definition of the lexical meaning (Snow, 1991). The objective of our study is to reveal metalinguistic awareness through the analysis of the structure and semantics of the bilinguals' definitions of the concrete nouns. We argue that the word definitions of Russian-Hebrew preschoolers in both languages manifest high metalinguistic awareness regardless of poor grammatical coherence and deviations in the lexical choice.

\section{Research Methods and Techniques \\ Исследовательские методы и процедуры}

We study the definition strategies that were revealed in the noun definitions generated by bilingual preschoolers in the formal definition test. The formal definition test is a tool to evaluate bilingual children's ability to comprehend lexical meanings (Snow et al., 1991). The test was conducted face to face with Israeli preschoolers in Russian and after a week wait interval in Hebrew (Minkov, 2018). The interviewer asked a preschooler to explain 14 nouns the best way he / she could to an alien unfamiliar with our civilization. The preschoolers' definitions were recorded in a non-share attention modus. This research is based on the interview with 56 preschoolers aged $5.0-6.8$ years. The dataset includes 1,564 definitions containing almost 12,000 word forms (6827 in Russian and 5166 in Hebrew).

Following the standard procedure to evaluate the definition quality (Snow et al., 1993: 94), we applied semantic analysis. Reference to the category by hypernyms, synonyms and co-hyponyms is considered as the adult-like definition. Since the children did not learn certain hypernyms (e.g., a 'limb'), we evaluate the general descriptive definition 
("this is something that...") containing a specific qualification as similar to the adult-like strategy. Thus, we discover six strategies the children used to define the nouns.

We applied one-way ANOVA to verify the impact of the language on the child's choice of the definition strategy.

\section{Results Результаты}

While explaining the meaning of the certain noun, the Russian-Hebrew bilinguals referred to: the category the object belongs to, the function of the object, its peculiarities, its parts or components. They also delivered a general description of the object or described a particular situation from their own experience. The instances of the definitions are displayed in Table 1.

\section{Table 1}

The instances of the bilinguals' definitions

\begin{tabular}{|c|c|c|c|}
\hline $\begin{array}{l}\text { Type of the } \\
\text { definition }\end{array}$ & Russian & Translation & Hebrew \\
\hline $\begin{array}{l}\text { Reference to the } \\
\text { category }\end{array}$ & $\begin{array}{l}\text { Цветок - это } \\
\text { растение. }\end{array}$ & $\begin{array}{l}\text { A flower is an herb. } \\
\text { A stool it is a chair without a back. }\end{array}$ & שרפרף זה כיסא בלי גב \\
\hline $\begin{array}{l}\text { Reference to the } \\
\text { function }\end{array}$ & $\begin{array}{l}\text { Нога - это ходить по } \\
\text { полу. }\end{array}$ & $\begin{array}{l}\text { A leg - it is for working on the floor. } \\
\text { (A knife) for cutting something }\end{array}$ & בשביל לחתוך משהו \\
\hline $\begin{array}{l}\text { Reference to the } \\
\text { peculiarity }\end{array}$ & $\begin{array}{l}\text { Часы - они делают } \\
\text { тик-так, потом } \\
\text { зазвенели - дзынь! }\end{array}$ & $\begin{array}{l}\text { A clock, it makes tick-tock, then it rang - } \\
\text { tink! } \\
\text { A word - it is something that comes out of } \\
\text { your mouth. }\end{array}$ & מילה - מה שיוצא לך מהפה. \\
\hline $\begin{array}{l}\text { Reference to parts } \\
\text { or components }\end{array}$ & $\begin{array}{l}\text { У него есть два } \\
\text { колёса, и тормоз, и } \\
\text { педали. }\end{array}$ & $\begin{array}{l}\text { (A bycicle) - it has two wheels, and } \\
\text { breaks, and pedals. } \\
\text { (A cow) - it has horns. It has brown and } \\
\text { sometimes pink spots. }\end{array}$ & 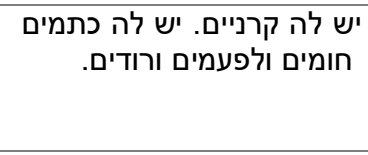 \\
\hline $\begin{array}{l}\text { Description of the } \\
\text { situation }\end{array}$ & $\begin{array}{l}\text { Зонтик это держут } \\
\text { чтобы не пролилось } \\
\text { когда дождик идёт } \\
\text { когда капельки воды }\end{array}$ & $\begin{array}{l}\text { They hold the umbrella so that it does not } \\
\text { spill when it rains when there are water } \\
\text { droplets. } \\
\text { Mother makes in the kitchen with the knife, } \\
\text { it is dangerous, mother cuts fruits with the } \\
\text { knife. }\end{array}$ & 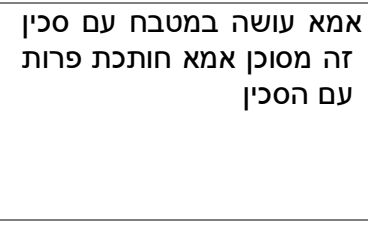 \\
\hline General description & $\begin{array}{l}\text { Шапка - это что-то, } \\
\text { что на голову мы } \\
\text { носим, она круглая. }\end{array}$ & $\begin{array}{l}\text { A hat is something that we wear on our } \\
\text { head, it is round. } \\
\text { A diamond is something that is very } \\
\text { expensive, it is full of sparkle, it is } \\
\text { beautiful. }\end{array}$ & 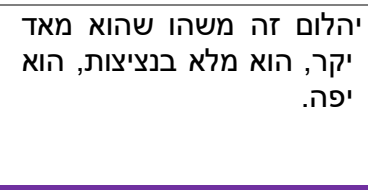 \\
\hline
\end{tabular}

The distribution of the definitions is represented in Table 2 and Figure 1. The essential impact of the language on the child's decision to choose one of the definition strategy or to reject the particular word is verified by $\operatorname{ANOVA}(\mathrm{F}(6,49)=4.1739, \mathrm{p}<0.05)$. 


\section{Table 2}

Types of the Russian-Hebrew bilinguals' definitions

\begin{tabular}{lllllllll}
\hline Language & Total & Failed & $\begin{array}{l}\text { Reference to } \\
\text { the } \\
\text { superordinate }\end{array}$ & $\begin{array}{l}\text { Reference } \\
\text { to the } \\
\text { function }\end{array}$ & $\begin{array}{l}\text { Reference } \\
\text { to the } \\
\text { peculiarity }\end{array}$ & $\begin{array}{l}\text { Reference to } \\
\text { parts or } \\
\text { components }\end{array}$ & $\begin{array}{l}\text { Description } \\
\text { of the } \\
\text { situation }\end{array}$ & $\begin{array}{l}\text { General } \\
\text { description }\end{array}$ \\
\hline Russian & 782 & 36 & 116 & 386 & 68 & 46 & 101 & 29 \\
\hline Hebrew & 782 & 135 & 72 & 290 & 87 & 22 & 61 & 115 \\
\hline Total & 1,564 & 171 & 188 & 676 & 155 & 68 & 162 & 144 \\
\hline
\end{tabular}

The reference to the function dominates in our dataset of the bilinguals' definitions. Nevertheless, the bilinguals often changed the definition strategy in their L2.

Fig. 1

Distribution of the Definitions in the Dataset

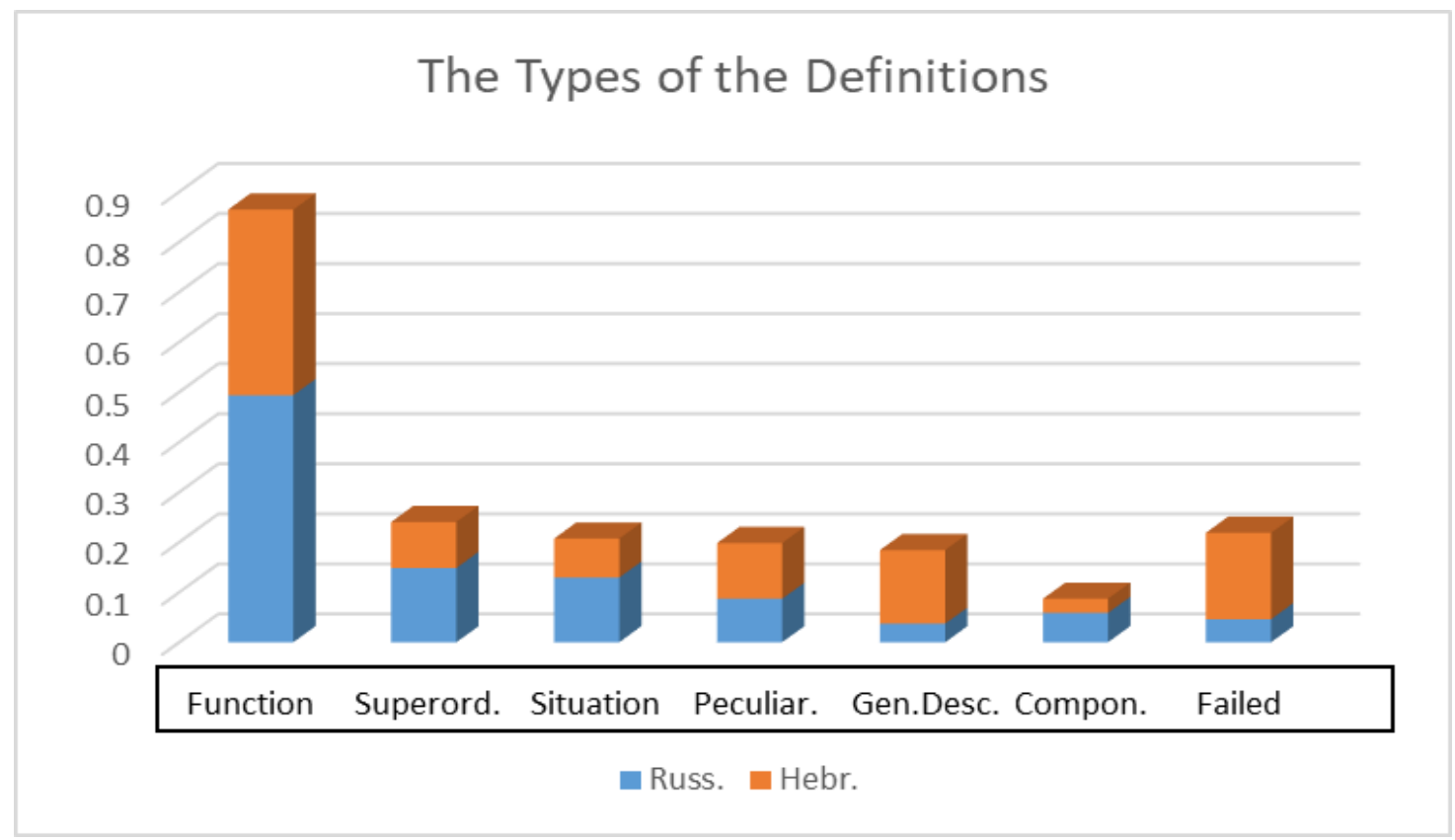

The children preferred references to the superordinate in Russian; however, they used general descriptions in Hebrew. While referring to the superordinate, bilinguals often used general nouns, especially in Hebrew. The children often described their own experience in Russian since it is their Heritage language to communicate with the family members. The preschoolers failed to recognize and explain some nouns: they failed in L2 three times as much as in L1.

The adult-like strategy (a reference to the category the object belongs to) occurs more often in Russian, than in Hebrew (see Table 3). 


\section{Table 3}

Types of the references to the superordinate in the definitions

\begin{tabular}{lllll}
\hline Language & $\begin{array}{l}\text { Total } \\
\text { references to } \\
\text { the category }\end{array}$ & $\begin{array}{l}\text { General noun ('thing', } \\
\text { 'object') }\end{array}$ & \multicolumn{2}{l}{ References to the particular category } \\
\cline { 3 - 4 } & 116 & $38(33 \%)$ & $53(46 \%)$ & Syponym / co-hyponym \\
\hline Russian & 112 & $33(46 \%)$ & $28(39 \%)$ & $25(21 \%)$ \\
\hline Hebrew & 72 & $115 \%)$ \\
\hline
\end{tabular}

In Russian, almost a half of the references to the superordinate include a hypernym. However, overgeneralization covers one third of the superordinate in Russian and almost a half of those in Hebrew. Nevertheless, two adult-like strategies (the superordinate and the general description strategies) cover 19\% (Russian) and 24\% (Hebrew) of the definitions.

\section{Conclusions}

Выводы

Altman et al. (2018) showed the impact of the metalinguistic awareness on the Hebrew vocabulary size among Russian-Hebrew bilinguals. Our results reveal the deficit in receptive and expressive vocabulary in Hebrew within the preschoolers. They probably allot less varied meanings to L2 words that is typical of bilinguals (Verhallen et al., 1993). They overused Hebrew general nouns due to the lack of the hypernyms in the vocabulary. Nevertheless, the children overcame the lack of category names thanks to the general description strategy manifesting their metalinguistic awareness. Metalinguistic awareness correlates with relatively high level of the executive control. Owing to the correlation, the bilinguals are able to adjust the semantic plan of the definition to their limited vocabulary.

\section{References Лuтература}

Altman, C., Goldstein, T., \& Armon-Lotem, S. (2018). Vocabulary, metalinguistic awareness and language dominance among bilingual preschool children. Frontiers in Psychology, 9, 1953. https://doi.org/10.3389/fpsyg.2018.01953

Bialystok, E., Peets, K.F., \& Moreno, S. (2014). Producing bilinguals through immersion education: Development of metalinguistic awareness. Applied psycholinguistics, 35(1), 177-191. https://doi.org/10.1017/S0142716412000288

Minkov, M. (2018). Osobennosti ispolzovanija testa definitsij sredi izrailskih detej-bilingvov [Peculiarities of the formal definition test among Israeli bilingual children]. Proceedings of the International Annual Conference "Problemy ontolingvistiki - 2018" - "Problems of Child Language studies -2018” (St. Petersburg, Match, 20-23, 2018) (pp. 178-182). Ivanovo. 
Minkov, M., Ovchinnikova I., \& Schwartz, M. (2020). Otrazhenie organizatsii leksikona v tolkovanijah russkih slov pjati-shestiletnimi bilingvami [Reflection of the lexicon structure in definitions of Russian words by bilingual children aged 5-6 years]. Izvestija RGPU im. A.I. Gertsena - Izvestia: Herzen University Journal of Humanities and Science, 196, 51-60. https://doi.org/10.33910/1992-6464-2020-196-51-60

Snow, C.E., Cancino, H., De Temple, J., Schley, S., \& Bialystok, E. (1991). Giving formal definitions: A linguistic or metalinguistic skill. Language processing in bilingual, 115(2), 90-112. https://doi.org/10.1017/CBO9780511620652.007

Verhallen, M., \& Schoonen, R. (1993). Lexical knowledge of monolingual and bilingual children. Applied linguistics, 14(4), 344-363. https://doi.org/10.1093/applin/14.4.344 